\title{
THE IMPROVEMENT AREAS OF SOCIAL PEDAGOGICAL ASSISTANCE PROVIDED TO PUPILS WITH EMOTIONAL AND BEHAVIOURAL DISORDERS
}

\author{
Gražina Šmitienė \\ Klaipeda University, Lithuania \\ Ilona Klanienè \\ Klaipeda University, Lithuania
}

\begin{abstract}
The article reveals problems and weaknesses of social pedagogical assistance provided to pupils with emotional and behavioural disorders (EBD) and provides insights into the development of social and educational support at schools. The qualitative research (focus group and interviews), in which there participated social workers and teachers (two groups of informants), has been conducted. The content analysis of the research findings has revealed the major weaknesses of assistance provided to pupils with EBD and its improvement areas: lack of professionals providing necessary help at schools, lack of teachers' special professional competences (the ability to recognize EBD problems, knowledge and skills of providing assistance), lack of cooperation between child assistance specialists, teachers, and parents (feedback problems), and a lack of motivation.
\end{abstract}

Keywords: social pedagogical assistance, pupils with emotional and behavioural disorders (EBD), social support at school, special professional competences.

\section{Introduction}

The research findings published by education researchers and practitioners reveal that the number of pupils with behavioural and/or emotional disorders (hereinafter referred to as EBD) at schools has been systematically increasing. As laid out in the Descriptor of the Procedure of Identification of Groups of Pupils with Special Education Needs and Division of their Special Education Needs into Groups approved by the Order of the Republic of Lithuania Minister of Education, Minister of Health, and Minister of Social Security and Labour (No. V-1265 / V685 / A1-317, 13 July 2011), the group with different disorders encompasses pupils with learning disorders (in two or more academic subjects: reading, writing, maths, and other), as well as emotional, behavioural, speech and language disorders that are revealed when children are mastering the curriculum, i.e. acquiring the key competences. In the document, emotional and behavioural 
disorders are defined as a heterogeneous group of disorders that occur as behavioural and emotional responses, sharply different from the usual age-related, cultural, and ethical norms, and that are also expressed by inattention, impulsivity, and/or poor behavioural regulation. The behavioural and/or emotional disorders include: attention deficit and hyperactivity disorder; behaviour (oppositional defiant disorder, anti-social behaviour) and emotional disorders (anxiety, mood spectrum disorders, etc.).

Miškinyte and Adomaitienė (2013) note that behavioural and/or emotional disorders are particularly exposed in adolescence. Khan et al. (2011), based on the findings of their research, assume that when this group of children regularly experience stress at school due to failures, they lose the opportunity of education in a free, unfettered environment. Galkienè (2009), Jokūbpreikšas and Bubnys (2013) state that the well-being for the teenagers with EBD can be ensured by well-timed social pedagogical assistance and support from adults (parents and teachers). While providing assistance to teenagers with EBD, not only the search for individual forms and methods of assistance is important, but also the choice of an educational paradigm which predetermines not only the attitude of teachers, but also the attitude of the society towards the assistance to children with special needs. The majority of researchers (Geležinienė et al., 2011; Frederickson \& Cline, 2011) support the idea of inclusive education, which is the most effective strategy of assistance provision to children with special needs, including children with EBD. Ališauskas et al. (2011) note that inclusion is associated with the elimination of barriers, i.e. the removal of all obstacles that disturb the qualitative provision of social educational assistance to all pupils and which ensures its availability.

While analysing the effectiveness of organizing the assistance to pupils with EBD, Geležinienè et al. (2011) suggest the use of the following strategies of assistance: behavioural modelling, application of a system of sanctions and encouragement, cognitive behaviour simulation (pupils are encouraged to understand and regulate their behaviour), systemic ecological modelling (focus on the change of environment by changing one's behaviour); medical behavioural modelling (medical treatment is needed to improve one's state). According to the authors, in order to pursue qualitative organization of assistance it is important to create a system of model harmonisation. Galkiene (2009) notes that the most important is to develop each child an individualized program which could ensure positive socialization and qualitative education (learning).

The accomplished studies distinguish the causes of change in the education system. The socialization and learning difficulties, conditioned by children's behavioural and/or emotional disorders, have received the greatest attention (Rippon, 2000). Special assistance to pupils with EBD and its limits are analysed 
more thoroughly and extensively. The research on the customization and differentiation of education is carried out by both foreign (Reicher, 2010; Frederickson \& Cline, 2011) and Lithuanian researchers (Ališauskas, 2007; Ališauskienė \& Miltenienè, 2004; Galkienè, 2009); also a huge emphasis is put on the issue of integration of pupils with EBD (Frederickson \& Cline, 2011). One of the most relevant issues is the organization of education (learning) and assistance to pupils with special needs. A number of studies have been conducted on the subject: Geležinienè et al. (2011) studied the organization of assistance to pupils with EBD, other researchers focused on the provision of special educational assistance to pupils with special educational needs (Ambrukaitis, 2012; Ališauskas et al., 2011; Gudonis et al., 2011). After revising the research of foreign and Lithuanian researchers, it is noticed that the problems faced by children with EBD in educational institutions, their expression and reasons were most frequently analysed, and a particular attention was paid to the discussions of issues regarding integrating pupils with special needs into the education system and organizing the process of assistance. In all studies it is stated that a special pedagogical assistance is not sufficient if considering a particular case of a pupil, although the resource of potential assistance in general education school is available. The content of social educational assistance to pupils with EBD in national schools is not sufficiently studied; a lack of researchers' attention to social educational assistance to pupils with EBD is observed.

The purpose of the research: the improvement areas of social educational assistance provided to pupils with emotional and behavioural disorders.

\section{Research Methodology}

The study has been conducted by gathering qualitative data (written opinions, group and private discussions). In order to clarify the content of social and educational assistance to pupils with EBD and the areas of assistance improvement, the qualitative research has been chosen (group discussion and interviews). In this stage it has been decided to go deeper into the experience of social workers and teachers-class tutors while supplying this kind of assistance. The said professionals are the closest to the pupils with special needs; they intensively cooperate with pupils and their parents and decide academic and social problems of pupils with EBD at school. According to Creswell (2009), a qualitative research enables to better understand the investigated phenomenon, reveals its characteristics, and discloses the peculiarities of attitudes.

In order to carry out the research, two methods have been selected: group discussion (with 9 social workers) and individual interviews (with 9 class tutors/teachers) from nine schools of Klaipeda city and district. Later, informants 
were asked to clarify certain aspects of the investigated problem in writing. In the process of selecting informants, the selection criterion has been applied. All the informants who participated in the research were women.

Firstly, individual structured interview with class tutors, working with 5th8th graders with behavioural and/or emotional disorders, has been performed. There have been chosen those class tutors who worked with 5th-8th grade students at different schools - it was intended to reveal a wider range of their experience, therefore, 9 interviews out of the 23 have been selected for the result analysis, i.e. those interviews during which informants emphasized the most important means of social educational assistance to pupils with EBD, analysed and argued the areas of social educational assistance, reflected their professional competences. The average work experience of teachers-class tutors was 12 years. It was important to investigate and to find out what teachers thought about the problems of social educational assistance to their students and which improvement areas they considered to be appropriate.

In the second stage of the research, a group discussion method has been selected, in which there participated social workers. It enabled to identify different experiences of social educational assistance provided at different schools, their similarities (similar weaknesses and strengths), on the basis of which the assistance to pupils with emotional and behavioural disorders could be improved, and the improvement areas of the identified problems. Participants of the group discussion (social workers) have enough experience necessary while providing assistance to pupils with EBD, also, by means of discussions they can provide fuller and more detailed answers, find similarities of provided assistance more quickly, and discern the common tendencies of social educational assistance. The average work experience of social workers was 8 years.

Content analysis. While analysing the results of interviews, it has been intended to distinguish those statements, which, according to the informants, emphasized the essential causes and conditions (e.g.: the most important, a fundamental basis, in the first place, only, the main condition, everything, and etc.) and which received the approval of the majority of the informants. During the content analysis, the statements of informants were grouped into several categories and subcategories (Creswell, 2009; Mayring, 2014). The data obtained during the research was divided into two categories: the content of social educational assistance to pupils with EBD; the improvement areas of social educational support to pupils with EBD. The informants, who had participated in the research, were introduced to the interview transcriptions; they specified the thoughts, expressed during the interview; then they were introduced to the results of the survey and their analysis. The research instrument. All the questions, provided to the informants, were formulated into a number of units: the content 
of social educational assistance to pupils with EBD and the areas of improvement of social educational assistance to pupils with EBD.

\section{Research Results and their Discussion}

While discussing the areas of improvement of social educational assistance to pupils with EBD, firstly it has been tried to find out what is the content of social educational assistance according to the informants. In this category - the content of social educational assistance to pupils with EBD - the opinions of informants were grouped regarding their importance (were identified by informants as the most significant) and their frequency (were mentioned by the majority of the informants) (Fig. 1). In another category - the areas of improvement of social educational assistance to pupils with EBD - three main subcategories were identified: regulation of EBD assistance at school, work with parents/parent education, and the development of teachers' competences (Table 1).

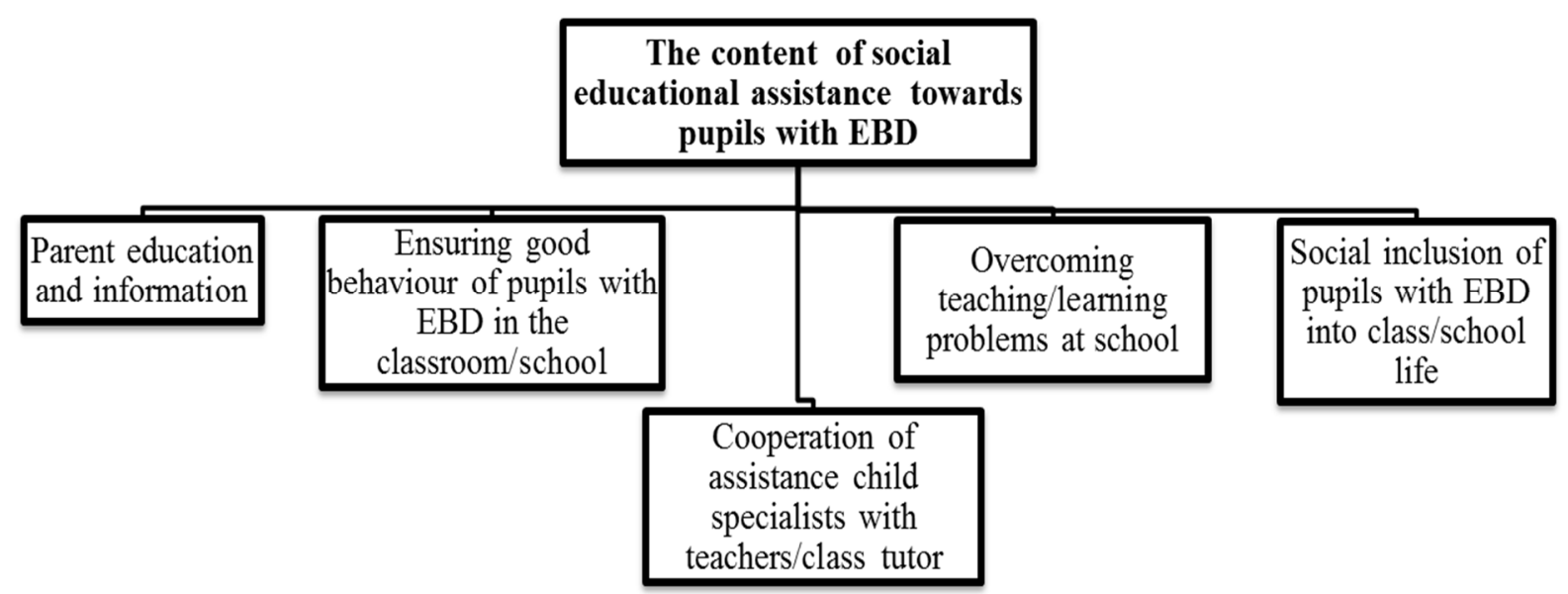

Fig. 1 Attitudes of social workers and class tutors regarding the content of social educational assistance to pupils with EBD

The content of social educational assistance. The participants of the qualitative research: teachers, class tutors and social workers unanimously asserted being providers of social pedagogical assistance to pupils with EBD. Class tutors emphasized that by being teachers of different subjects they seek to deal with the problems of not only teaching or learning. All the participants of the research highlighted the problems concerned with misbehaviour, discipline at school and in the classroom of pupils with EBD, also related teaching (learning) difficulties, disturbances of communicating with peers and etc. During group discussions and individual interviews, the informants emphasized the issues of identification, diagnosis and naming of the problem of pupil's misbehaviour. They also emphasized that firstly there are noticed theproblems in child's behaviour, i.e. discipline in the classroom, violations of coexistence rules at school, and etc. 
Special pupils' needs, i.e. emotional and behavioural disorders, are revealed only by going deeper into the causes of such behaviour. Associating reasons of the improper behaviour in the classroom and at school with pupil's behaviour and emotional disorders, also competent diagnosis of this is a huge challenge for both teachers and the family of a pupil. Geležiniene et al. (2011) note that one of the main challenges for educators is to identify the needs of children with special educational needs, to understand the peculiarities of education of these children, to organize work in heterogeneous groups. Most often the family does not agree to consult the professionals in order to identify this problem. The informants mentioned that the pupil's parents often, even having the conclusions and recommendations from the professionals of child assistance services, deny these problems or hide them from teachers, "parents do not say, even if they know", "deny", "they [the parents] keep silent", "assert that inadequate requirements are applied to their child", and etc. According to the informants, parents usually react to the fact of recognition of emotional behavioural disorders of their child in three ways: do not know, hide, deny. While talking about working with parents, social workers and class tutors also emphasize their lack of competence in reasonably revealing parents that the causes of problems of regressive and (or) undisciplined pupil must be sought for in a joint effort, that they need to be addressed quickly, that belated solution to the problem might be harmful to their child, have negative consequences. Educators note that unlike other special needs (vision, hearing or other physical impairments), emotional and behavioural disorders tend to be justified as a feature of the personality. It is also justified as teachers' reluctance to accept pupils with "their opinion", teachers' reluctance to work with "free", "other generation", "modern" pupils.

Table 1 Informants' views on improvement areas of social educational assistance to pupils with EBD

\begin{tabular}{|c|c|l|}
\hline $\begin{array}{c}\text { Sub- } \\
\text { categories }\end{array}$ & $\begin{array}{c}\text { Groups of } \\
\text { infor- } \\
\text { mants }\end{array}$ & \multicolumn{1}{|c|}{ Examples of statements } \\
\hline $\begin{array}{c}\text { EBD } \\
\text { assistance } \\
\text { regulation } \\
\text { at school }\end{array}$ & $\begin{array}{c}\text { Class } \\
\text { teachers }\end{array}$ & $\begin{array}{l}\text { "The fact that it is completely unclear, whether to look for } \\
\text { solutions individually, or to address the Child Welfare Committee", } \\
\text { "most importantly, nobody at the school knows who has to solve } \\
\text { the problems", "you are left alone in the class dealing with the } \\
\text { problems", "it is only not clear how to organize work in the } \\
\text { classroom" }\end{array}$ \\
\cline { 2 - 4 } & $\begin{array}{l}\text { Social } \\
\text { workers }\end{array}$ & $\begin{array}{l}\text { "The best thing would be that psychologists would work with } \\
\text { them", "the essence is that teachers have to know how to attract } \\
\text { pupils' attention, instead of sending them to us", it is completely } \\
\text { unclear who face more difficulties: children, parents or teachers", }\end{array}$ \\
\hline
\end{tabular}




\begin{tabular}{|c|c|c|}
\hline & & $\begin{array}{l}\text { "how to evaluate the assistance to a child", "it is absolutely not } \\
\text { clear how to provide feedback to parents" }\end{array}$ \\
\hline \multirow{2}{*}{$\begin{array}{l}\text { Working } \\
\text { with } \\
\text { parents / } \\
\text { parent } \\
\text { education }\end{array}$} & $\begin{array}{c}\text { Class } \\
\text { teachers }\end{array}$ & $\begin{array}{l}\text { "everything depends on the family", "parents rush to defend, } \\
\text { because they believe that it faults will be find in them", "it is } \\
\text { difficult to get information on how the problem is solved within the } \\
\text { family" }\end{array}$ \\
\hline & $\begin{array}{c}\text { Social } \\
\text { workers }\end{array}$ & $\begin{array}{l}\text { "If a mother simply denies a problem", "nothing is possible when } \\
\text { a mother keeps silent", "parents collectively hid that the child was } \\
\text { diagnosed with EBD needs" }\end{array}$ \\
\hline \multirow[t]{2}{*}{$\begin{array}{l}\text { Develop- } \\
\text { ment of } \\
\text { teaching } \\
\text { competen- } \\
\text { ce }\end{array}$} & $\begin{array}{c}\text { Class } \\
\text { teachers }\end{array}$ & $\begin{array}{l}\text { "It is difficult to understand that a serious problem is hiding } \\
\text { beneath this", "it is completely unclear how to work with these } \\
\text { pupils", "there are absolutely no seminars about the methods of } \\
\text { work with such pupils", "there is lack of skills of how to help other } \\
\text { children in the classroom to get on well with them". }\end{array}$ \\
\hline & $\begin{array}{c}\text { Social } \\
\text { workers }\end{array}$ & $\begin{array}{l}\text { "Most importantly, how to identify that there are EBD problems, } \\
\text { not just bullying", "lack of arguments, how to make parents believe } \\
\text { that a child needs special assistance", "it is very necessary to gain } \\
\text { skills how to explain parents how they can help", "lack of } \\
\text { techniques, tests, how to verify that pupil's problem is EBD" }\end{array}$ \\
\hline
\end{tabular}

Informants believe that in order to help their child parents choose inappropriate means: move the child to another school, prohibit the child to interact with other pupils, accuse the other students and their parents of negative attitude towards their child, do not allow any extra-curricular activity, etc. The research results by Ališauskas (2007) revealed that one of the essential barriers for the provision of social educational assistance is the lack of positive cooperation between teachers and parents. The majority of the researchers who have studied the peculiarities of social educational assistance to different groups of children (Ilgūnienè \& Griškevičiūtè, 2012) emphasize that cooperation between professionals and a family must be based on partnership, which is expressed by equivalent interpersonal relationships, parents' involvement into the process of dealing with their child's problems, exchange of knowledge, expectations, strategies, resources (Kairienè, 2010). While discussing teaching (learning) difficulties, arising with/for pupils with EBD, social workers and teachers, emphasized the necessity for proper behaviour, attention, concentration, enforcement of discipline not only during classes, but also in involving pupils in extra-curricular activities. Social workers stressed the importance of extracurricular activities for pupils with EBD. The informants noted that a timely assistance, which enables to construct proper communication with classmates and to maintain social relationships at school, usually helps these children to overcome education (learning) difficulties and to gain new social skills in extracurricular activities. Proper behaviour with classmates and teachers was mentioned as an important aspect by social workers, who indicated that it is an 
essential condition for pupils with EBD to be socially engaged into the class/school. Researchers, performing studies in the field of social pedagogical assistance (Ališauskas et al., 2011) consider peer support, customized training, applied behaviour analysis, positive behaviour support at school; development of social skills as effective strategies to help children with special needs to learn at school. It should be noted that both groups of informants (during group discussions and individual interviews) expressed the importance of close cooperation between child assistance specialists and teachers. The informants indicated that such cooperation is essential in providing social pedagogical assistance to family and child.

Improvement areas of social educational assistance to pupils with EBD. Social workers and class tutors noted various improvement areas of social educational assistance to pupils with EBD. From all the surveyed teachers, there can be distinguished three subcategories of opinions regarding the improvement areas of social educational assistance: regulation of EBD assistance at school, work with parents/parent education, development of teacher competences to assist students with EBD (Table 1). The informants link the regulation of assistance at school not only with the organizational procedures and competency to define problems, but also with the necessity of recommendations for working with pupils with EBD, methodological tools, instruments, which could help school teachers to differentiate / associate occurring student's behavioural problems with EBD. Ambrukaitis et al. (2012) emphasize the responsibility of specialists in providing possible directions and methods of remedial educational work. According to the researchers, while providing the direction of educational remedial work, it is important to take into account not only the characteristics of the disorders, but also individual child's needs, abilities (Labinienė \& Ruškus, 2003; Geležinienè et al., 2011).

As noted by the informants, regulation of EBD assistance should include the recommendations for working with parents, provision of proper feedback of social and educational support for participants. The assessment of social pedagogical assistance was identified as a particularly important aspect, associated not only with the quality of assistance received at school, but also with feedback supply among assistance participants, opportunity for all assistance child specialists to assess and evaluate themselves timely. The importance of assessment is highlighted by the majority of scientists.

In the subcategory of the work with parents informants emphasized the necessity of parent education and awareness regarding the characteristics of emotional behavioural disturbance, opportunities of correction, educational assistance and long-term consequences because of failure to receive timely assistance. The informants emphasized that in the process of assistance provision 
to pupils with EBD, there should be provided the methods of parents inclusion into the process of assistance supply; the recommendations of how to properly adjust the child's behaviour at home, how to encourage the participation in class/school life, how to encourage children to behave in the classroom properly, how to help children overcome learning (learning) difficulties must be also prepared. During the interview social workers noted that, by providing assistance to pupils with behavioural and emotional disorders, they seek to promptly and fully inform parents and encourage them to actively cooperate with school teachers. Kairienè (2010), Ilgūnienè and Griškevičiūtè (2012), referring to the results of cooperation among team members in providing assistance to children with special education (learning) needs, strongly emphasize the importance of cooperation between team members and family. While providing social educational assistance, cooperation among pupils' parents, social workers and class teachers is very important.

In the subcategory of the development of teachers' competence, teachers emphasized the usual feeling of helplessness to promptly and properly identify the causes of pupil's misbehaviour, to provide assistance to pupil during school hours, what are learning peculiarities of EBD pupils, how to deal with problems of inappropriate behaviour with classmates, "nobody explains how to clarify a lesson to such pupils", "it is absolutely not clear how to work with those pupils". The development of both general and the special competences enables social workers to provide assistance to the client more efficiently and professionally (Leliūgienè \& Terechovienè, 2011). The studies by Gudonis and Mockevičiūtè (2008) have revealed that many teachers are not prepared to educate children with special needs, therefore, negative attitudes, reluctance to work with these children still dominate in educational institutions.

During the discussion social workers agreed with a view of a lack of properly prepared diagnostic methodology and recommendations regarding social pedagogical work with EBD pupils (fig.2).

While the number of pupils with emotional and behavioural disorders at schools is increasing, there is observed not only the lack of specialists, providing necessary help for a child, but also the necessity to prepare high-quality social educational recommendations for teachers, social workers, parents, regarding the education of children with EBD. These recommendations are relevant to all school professionals because, as shown by the research results, one of the most effective factors of social educational assistance is a coordinated teamwork between teachers and professionals. 


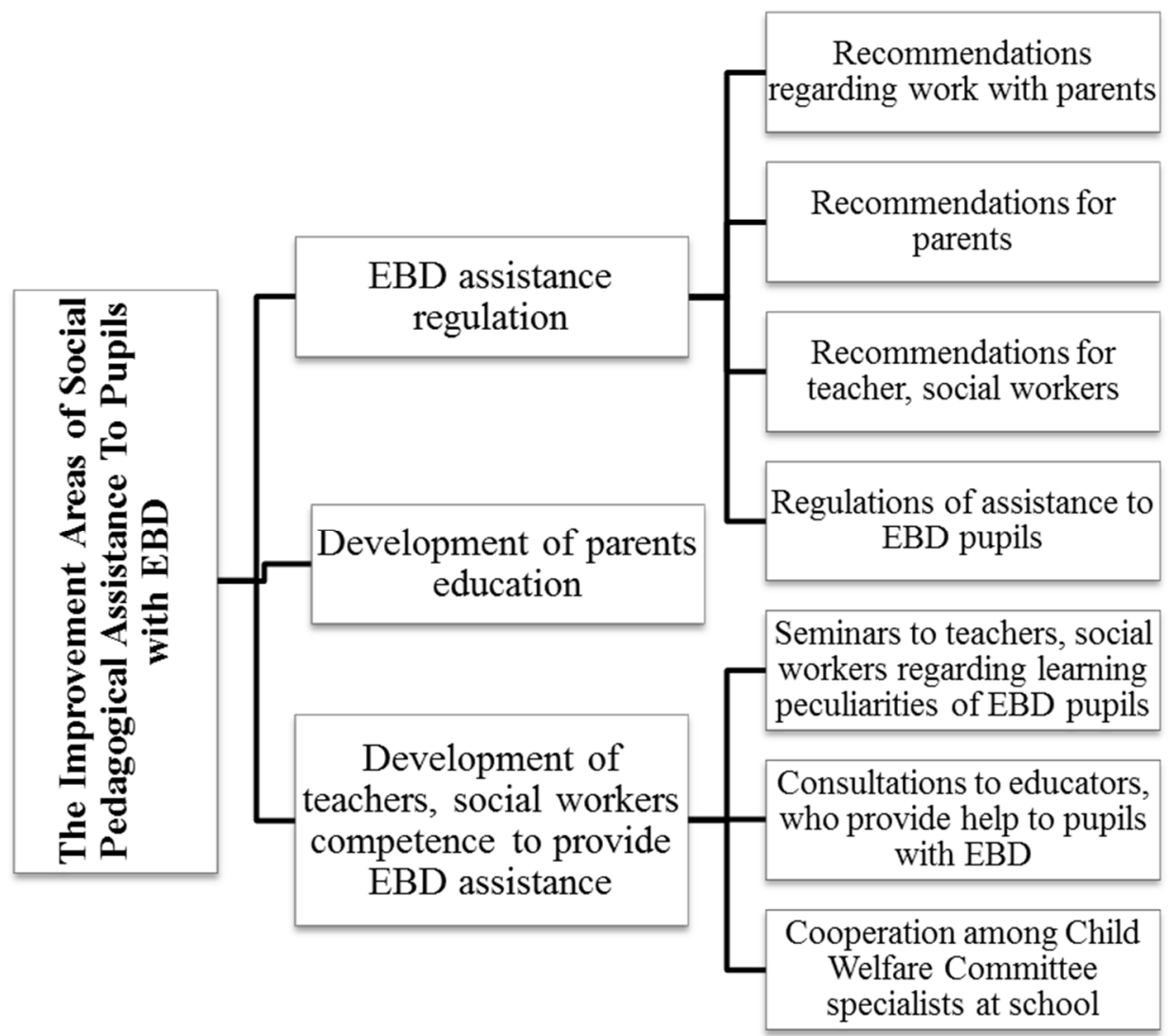

Fig.2 Attitudes of social workers and class teachers regarding the improvement areas of social educational assistance to pupils with EBD

\section{Conclusions}

After summarizing the data of the qualitative research, it can be stated that teachers and social workers are faced with various problems at schools, while providing assistance to pupils with behavioural and emotional disorders: i.e. parent education and supply with information, ensuring appropriate behaviour in the classroom/at school of EBD pupils, cooperation of assistance child specialists with teachers, class tutors, dealing with teaching (learning) problems at school, social involvement of pupils with EBD into the class/school life. The content of social educational assistance to EBD children, highlighted by the informants, points out the following most important areas of this development: regulation of assistance to pupils with EBD, improvement of parent education, development of teachers and social workers competence to provide assistance to pupils with EBD. 


\section{References}

Ališauskas, A. (2007). Vaiko psichopedagoginis vertinimas: pokyčiu perspektyva. Šiauliai: Publishing House of Šiauliai University.

Ališauskas, A., Ališauskienė, S., Gerulaitis, D., Kaffemanienė, I., Melienė, R., \& Miltenienė, L. (2011). Specialiuju ugdymo(si) poreikiu tenkinimas: Lietuvos patirtis užsienio šaliu kontekste. Śiauliai. Downloaded from: http://www.su.lt/bylos/fakultetai/socialines_ geroves_ir_negales_studiju/mokslo\%20studija.pdf.

Ališauskienè, S., \& Miltenienè, L. (2004). Bendradarbiavimas tenkinant specialiuosius ugdymosi poreikius. Šiauliai: Publishing House of Šiauliai University.

Ambrukaitis, J. (2012). Specialiojo ugdymo kaitos bruožai. Šiauliai: Publishing House of Šiauliai University.

Creswell, J. W. (2009). Research Design: Qualitative, Quantitative, and Mixed Methods Approaches. 3rd Edition. Los Angeles: Sage Publications.

Frederickson, N., \& Cline, T. (2011). Special educational needs, inclusion and diversity. Maidenhead: Open University Press.

Galkienè, A. (2009). Asmens lygiavertiškumo puoselëjimas - orios asmenybès ugdymo prielaida. Pedagogika. No. 95, 45-52.

Geležinienè, R., Vasiliauskienė, L., \& Vyšniauskienè, A. (2011). Mokomès kartu. Metodinès rekomendacijos mokytojams ir švietimo pagalbos teikejjams. Vilnius: National Centre for Special Needs Education and Psychology.

Gudonis, V., Rusteika, M., \& Ališauskas, A. (2011). Specialiosios pedagoginès pagalbos teikimas bendrojo lavinimo mokyklose: mokinių ir mokytojų požiūris. Pedagogika, No. 101, 91-97.

Ilgūnienè, R., \& Griškevičiūtè, D. (2012). The involvement of Social educators in the Cultivation of Family Values. Socialinis ugdymas, 30(31), 90-99.

Jokūbpreišas, L., \& Bubnys, R. (2013). Paauglių mokyklos baimès ir elgesio bei emocinių sunkumų tarpusavio sąsajos. Mokslas ir edukaciniai procesai, No. 1 (16). Downloaded from: http://oaji.net/articles/2014/348-1393684179.pdf.

Kairienè, D. (2010). Komandos narių bendradarbiavimas teikiant ankstyvają pagalbą vaikui ir šeimai: atvejo analizè. Specialusis ugdymas No. 1 (22), 84-96.

Khan, M. A., Ali, A., \& Mufti, T. (2011). Beneath The Surface: An Investigation of School Related Fears and Harassment. Dialogue. Vol. 6, Issue 4, 398-409.

Mayring, Ph. (2014). Qualitative content analysis. Theoretical foundation, basic procedures and software solution (free download via Social Science Open Access Repository SSOAR, URN: http://nbn-resolving.de/urn:nbn:de:0168-ssoar-395173).

Miškinytė A., \& Adomaitienè V. (2013). Nerimo ir depresijos simptomų raiška adaptacijos sutrikimu atveju. Sveikatos mokslai, 6, 50-53.

Reicher, H. (2010). Building inclusive education on social and emotional learning: challenges and perspectives - a review. International Journal of Inclusive Education, 14, 213-246.

Rippon Thomas, J. (2000). Aggression and violence in health care professions. Journal of Advanced Nursing, 31, 2, 452-460. 